\title{
Developmental consequences of embryo and cell manipulation in mice and farm animals*
}

\author{
Thomas G. McEvoy, John J. Robinson and Kevin D. Sinclair \\ Scottish Agricultural College, Animal Biology Division, Craibstone Estate, Bucksburn, \\ Aberdeen AB21 9YA, UK
}

\begin{abstract}
Advances in biotechnology in recent decades have revolutionized our understanding of early mammalian development and promise to provide ever more finely tuned and precisely targeted techniques for genetic enhancement of domestic animal species. In demonstrating what is both technically and biologically possible, not only in mice but also in larger animal species, research has provided hope that previously intractable diseases and genetic defects can be successfully combated. Crucial to this research is the ability to culture oocytes, embryos and somatic cells in vitro and to sustain their development without inducing adverse short- or long-term consequences. There is a need to refine current culture strategies in farm animal species to avoid jeopardizing their dependent technologies. A key to resolving current limitations of culture strategies is to identify, acknowledge and then address those features of in vitro culture that compromise early regulation of mammalian development. The aim of this review is to appraise critically in vitro embryo and somatic cell production strategies in the context of their impact on developmental competence and normality at embryonic, fetal and later stages. In addition, effects of physically manipulating embryos and cells, most notably via nuclear and gene transfer technologies, are considered with a view to identifying how detrimental consequences can be avoided.
\end{abstract}

Recent advances in gamete and embryo manipulation are transforming mammalian reproduction and biotechnology. Some advances have rescinded long-held 'certainties' and also promise to improve the odds in the battle against cancers, hereditary diseases and other illnesses. Scientists today are privileged to witness and contribute to this unfolding story. Privilege, however, brings responsibilities, primarily to ensure that normal development is safeguarded. It is important to monitor the consequences, positive or adverse, of our actions in manipulating gametes (both oocytes and spermatozoa), embryos and cells, whether such manipulation be via exposure to artificial environments, microinjection, nuclear transfer, genetargeting or other means.

The large offspring syndrome (LOS), first reported in cloned calves (Willadsen et al., 1991) and then after in vitro culture of intact embryos (for review, see Young et al., 1998), demonstrates that manipulation of the environment of an embryo can alter subsequent fetal, placental and periand post-natal development profoundly in farm animals (McEvoy et al., 1998; Sinclair et al., 1999; Peterson et al.,

Email: t.mcevoy@ab.sac.ac.uk

*This article is based on a presentation given at the British Society of Animal Science symposium 'Early Regulation of Mammalian Development' held in Aberdeen in September 2000.
2000; van Wagtendonk-de Leeuw et al., 2000). This essentially biochemical manipulation of early-stage embryos reflects two features of in vitro culture. Firstly, the egg is removed from the oviduct and uterus, which normally provide developmental cues and trophic signals orchestrated to safeguard development of the new entity. Secondly, in vitro environments, being thus far based more on empiricism than on precise knowledge of embryo needs, inevitably provide a discordant repertoire of biochemical signals that confound the genetic blueprint of at least some embryos. When such disruption coincides with the commencement of embryonic genome activation (from the two-cell stage onwards, depending on species) errors may increase even though, in contrast to some physical manipulations, genetic codes are conserved. Ironically, the subacute nature of at least some of the aberrant changes induced by in vitro production of embryos allows the changes to remain undetected in the short term. Blastocyst production, a hallmark for the efficiency of in vitro embryo culture systems, can often be achieved despite detrimental environmental effects. Indeed, Walker et al. (1992) reported that more blastocysts were produced from ovine zygotes in vitro than from equivalent zygotes in vivo. This finding should cause us to question the normality of blastocysts produced in artificial environments where subnormal embryos are perhaps less stringently de-selected than in dynamic conditions in vivo. 
This article reviews some of the short- and long-term changes that can be wrought in mammalian oocytes and embryos up to the blastocyst stage (Table 1), and also in somatic and germline cells, by culture or physical manipulation.

\section{Impact of in vitro environments}

A major requirement for normal long-term development of domestic animal embryos, whether generated entirely in vivo or produced in vitro, is that sufficient numbers of their constituent somatic cells are diploid. Although mixoploidy is a common occurrence in morphologically normal domestic animal embryos, ploidy may be compromised further as a consequence of conventional in vitro production. For example, Viuff et al. (1999) reported that the incidence of mixoploidy was significantly higher among bovine blastocysts produced in vitro than among in vivo embryos from superovulated donors (78 versus 25\%); furthermore, $17 \%$ of in vitro blastocysts but none of those produced in vivo had a $>10 \%$ incidence of polyploidy. As noted by Viuff et al. (1999), advances in detection techniques, for example the availability of chromosomespecific probes for fluorescence in situ hybridization (FISH) analysis, are beginning to provide more informative data for individual embryos than were previously available. Thus, it should soon be possible to determine the extent to which mixoploidy is aggravated by in vitro culture and whether, as a consequence, subsequent development is distorted. In one study in mice, James et al. (1995) reported that diploidtetraploid chimaeras exhibited retarded development at day 7.5 of gestation and placental overgrowth at day 12.5. This placental overgrowth may have been a consequence of the fact that tetraploid cells were preferentially allocated to extraembryonic membranes, but it is not yet known whether the same phenomenon occurs in domestic animal species.

\section{Gene expression}

Early post-fertilization embryonic genome activation occurs gradually and includes ribosomal RNA (rRNA) gene activation, a prerequisite for the synthesis of proteins with housekeeping and other roles (Hyttel et al., 2000a). Ribosomal RNA gene activation in pig embryos can be adversely modified in culture (Hyttel et al., 2000b), with the result that localization of essential nucleolar proteins is lacking in in vitro derived embryos compared with embryos produced in vivo (Hyttel et al., 2000a). Laurincik et al. (2000) described some key features of rRNA gene activation in bovine embryos in vitro, but equivalent data for in vivo embryos have not been reported.

In addition to rRNA gene expression, scrutiny of other transcripts has been used to elucidate effects of culture in a number of animal species. Included in such studies are stress-sensitive genes that fulfil various protective roles in preimplantation embryos. In response to elaborate developmental checkpoint criteria aimed at co-ordinating the multiplicity of events during cell proliferation, these and other genes overcome set-backs during development by slowing or arresting growth to facilitate repair of damage or, where this is excessive, by recourse to selective induction of cell death (King and Cidlowski, 1998). Accordingly, significant increases in the abundance of transcripts from such specialized genes are indicative of the reaction of the embryo to adverse artificial conditions. At Aberdeen, W. D. Rees and colleagues have investigated the expression of growth arrest genes such as gas5, gas6 and CHOP-10 (gadd153) in mouse and cattle embryos and in bovine granulosa cells cultured in vitro (Fleming et al., 1997; Fontanier-Razzaq et al., 1999, 2001). These studies have helped to determine the impact of culture constituents, notably serum, on embryonic well-being in vitro and may lead to the identification of culture systems that avoid imposing negative developmental stresses on the embryo. When embryonic damage cannot be repaired, cell death may be an inevitable and sometimes self-imposed consequence. This 'self-pruning' strategy mimics normally programmed cell death or 'apoptosis', which is a natural and necessary mechanism used, even in optimal conditions, to sculpt and manage mammalian development, from earliest embryonic cell lineages through to adult limbs (Allan et al., 2001). However, growth arrest and apoptosis may be invoked during culture to an extent that is severely detrimental or even lethal. Moreover, once they have been induced, these processes might not subsequently be sufficiently or appropriately deregulated in artificial environments, for example when such conditions prevent proper regulation of the balance between these and the antagonistic processes of cell proliferation (for a review, see King and Cidlowski, 1998).

The precise threshold beyond which apoptotic activity becomes detrimental to the early embryo is not known, although conditions wherein the number of cells is significantly compromised are generally considered to be suboptimal. An example is the study by Byrne et al. (1999) in which the presence of fetal calf serum was associated with increased apoptotic activity and a reduction in the number of blastocyst cells. In this report, apoptosis was detected predominantly in the inner cell mass (ICM), unlike the situation in mice or humans in which the occurrence of apoptosis in blastocysts produced in vitro is more random and includes trophectoderm (TE) cells (Jurisicova et al., 1998; Hardy, 1999). Taking into account the likely impact of apoptosis on both ICM cell populations and ICM:TE ratios, Byrne et al. (1999) concluded that any alteration in the extent of cell death could influence subsequent fetal development. The implications of alterations in the extent of cell death would depend on whether healthy and vital cells were killed or, in circumstances of depressed apoptotic activity, whether abnormal cells survived. There is not yet any definitive link between the incidence of apoptosis in in vitro derived mammalian embryos and the normality or otherwise of subsequent fetal development.

In addition to the rRNA and stress-sensitive gene 
Consequences of mammalian embryo and cell manipulation

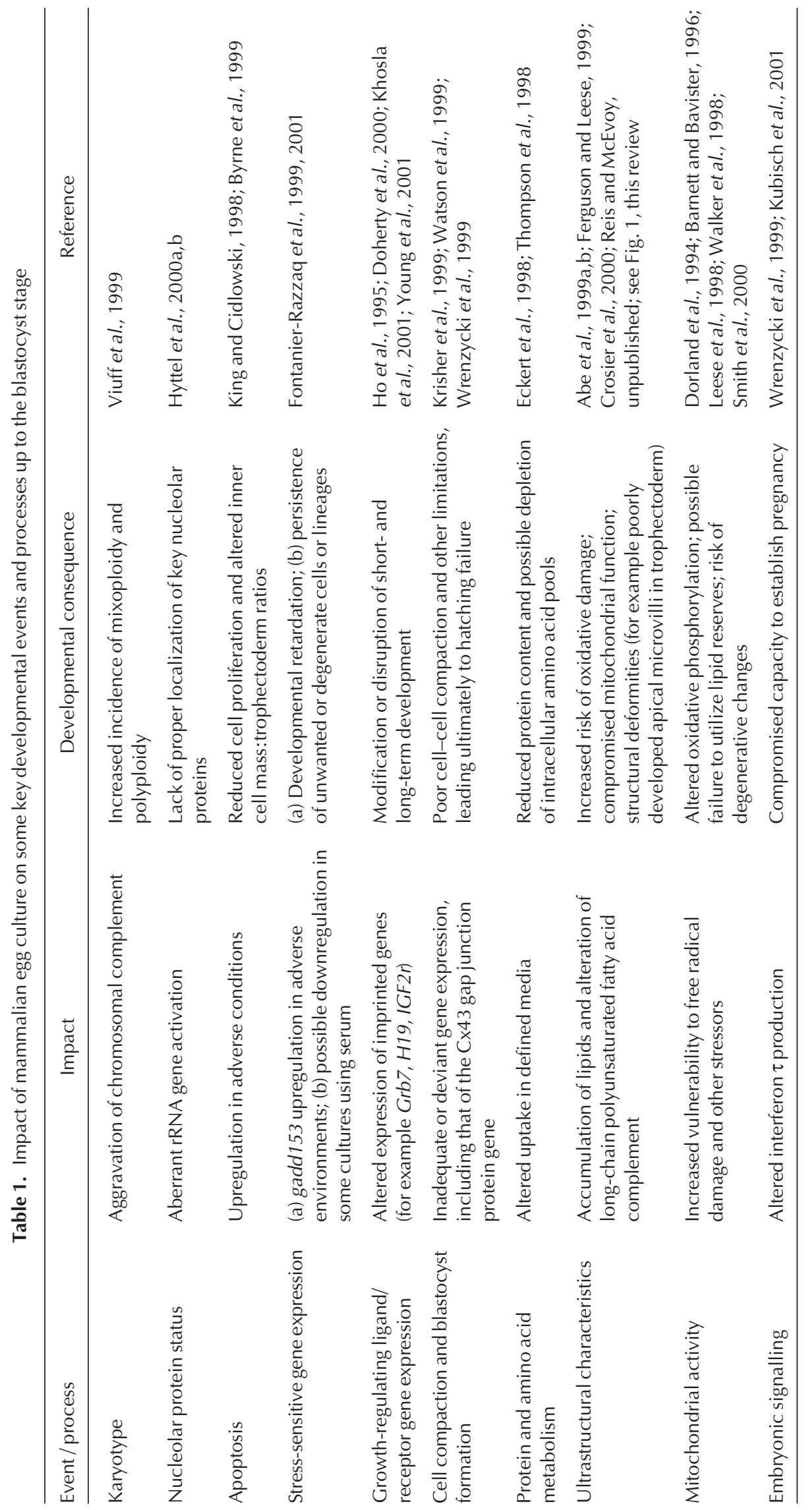


expression studies, several reports have cited differences between embryos produced in vivo and in vitro in respect of transcripts required for other developmental processes (for a review, see Niemann and Wrenzycki, 2000). Likewise, a number of reports contrast gene expression patterns among embryos generated in different culture conditions in vitro. Ho et al. (1995) observed that culture of mouse embryos in potassium simplex optimized medium (KSOM) supplemented with amino acids induced gene expression patterns that closely resembled those of in vivo embryos and which, in respect of insulin-like growth factor receptor I (IGF-I), IGF-II and IGF-II receptor genes, for example, exceeded the amounts of transcript detected after culture in Whitten's medium. Wrenzycki et al. (1999) reported that connexin 43 mRNA transcripts were detectable throughout development in bovine embryos cultured in medium supplemented with polyvinyl alcohol (PVA) but were virtually absent between the 8-16-cell and hatching stages in embryos cultured in the presence of serum. The same authors observed that the abundance of mRNA transcripts for interferon $\tau$, a glycoprotein required for maternal recognition of pregnancy, was significantly increased at the hatched blastocyst stage only in embryos cultured in the presence of PVA. They concluded that gene expression in bovine embryos exposed to exogenous protein in vitro was affected in a stage-specific manner. However, Kubisch et al. (2001) suggested that increased interferon $\tau$ production by bovine embryos cultured in the presence of PVA may be a stress-responsive reaction by the embryos to suboptimal culture conditions.

\section{Embryo composition and constituent integrity}

Many reports have demonstrated that 'blastocyst stage domestic animal embryos' produced in vitro differ from those produced in vivo (Thompson, 1997; Holm and Callesen, 1998; Abe et al., 1999a), and the extent of these differences is dictated by the in vitro production system used (Thompson et al., 1995, 1998; Abe et al., 1999b; Krisher et al., 1999). In general, extended exposure of embryos to serum-supplemented media results in more marked changes than exposure to supplements such as albumin or other macromolecules (Thompson et al., 1995; Wrenzycki et al., 1999; Crosier et al., 2000). Ferguson and Leese (1999) reported nearly twofold increases in the triglyceride content of bovine embryos cultured to the blastocyst stage in the presence of serum, and a number of authors have observed that lipid inclusions are a feature of morulae and blastocysts generated in the presence of serum (see McEvoy et al., 2000a) (Fig. 1). Such exogenously derived lipids tend to be enriched with polyunsaturated fatty acids (PUFAs) and consequently constitute a threat to cattle, sheep and pig embryos, which have been shown preferentially to avoid long-chain PUFAs in their endogenous reserves (McEvoy et al., 2000b). The most significant threat, aside from complications posed during conventional cryopreservation (Pollard and Leibo, 1994), is that of oxidative damage to which the preimplantation embryo is susceptible. Therefore, it is not surprising that Pangestu et al. (1996) were able to demonstrate that injection of $\alpha$-tocopherol, a potent antioxidant, improved cryo-survival of bovine embryos produced in vitro. NasrEsfahani et al. (1990) noted that mouse embryos produced in vitro generated more hydrogen peroxide than did embryos produced in vivo, predisposing embryos produced in vitro to a greater risk from reactive oxygen species. Cattle embryos seem less able than mouse embryos to express antioxidant genes during early development (Harvey et al., 1995) and expression of these genes is also stagedependent: 9-16-cell eggs are better able to combat oxidative stress than are either zygotes or blastocysts (Van Langendonckt et al., 1998). One popular strategy aimed at minimizing oxidative stress in vitro is to culture embryos in 'low oxygen atmospheres' (see Bavister, 1995; Barnett and Bavister, 1996; Thompson, 1996).

In contrast to mere compositional changes, which can perhaps be offset by recourse to antioxidants, the occurrence of degenerative anomalies in mammalian embryos poses a sinister threat to the viability and continued normal function of blastocysts produced in vitro. For example, Abe et al. (1999a) reported that apical microvilli and cell-cell junctional complexes were not as well developed in the trophectoderm of blastocysts produced in the presence of serum as in in vivo-derived blastocysts. The presence of protein during embryo culture has been associated with degenerative changes in mitochondria. Crosier et al. (2000) reported that compact morulae produced in vitro had fewer mitochondria but more lipid than did those produced in vivo, and that morulae produced in the presence of serum throughout culture were the most deviant. Although there is not yet any definitive evidence linking altered mitochondrial localization or appearance with either concurrent or later developmental repercussions (Krisher and Bavister, 1998), it is difficult to imagine that severe degeneration could occur with impunity. Leese et al. (1998) speculated that increased glycolytic activity of embryos cultured in the presence of serum reflects mitochondrial degeneration of the type reported by Dorland et al. (1994). Likewise, Barnett and Bavister (1996) noted that free radical-induced mitochondrial damage could be the reason for altered embryo metabolism in vitro. It has been suggested that, in circumstances of mitochondrial degeneration, genomes of surviving mitochondria mutate more frequently than normal (Walker et al., 1998).

\section{Large offspring}

It has been stated that changes induced by the in vitro environment per se are achieved without altering the fundamental genetic code of an individual. However, access to that code and the means whereby it is deciphered, phenotypically expressed, or perhaps eventually transmitted, can be altered in vitro. This scenario extends beyond upregulated expression of genes with apoptotic or growth arrest roles because, albeit probably at amounts and times at odds with normal expression in vivo, these stress- 

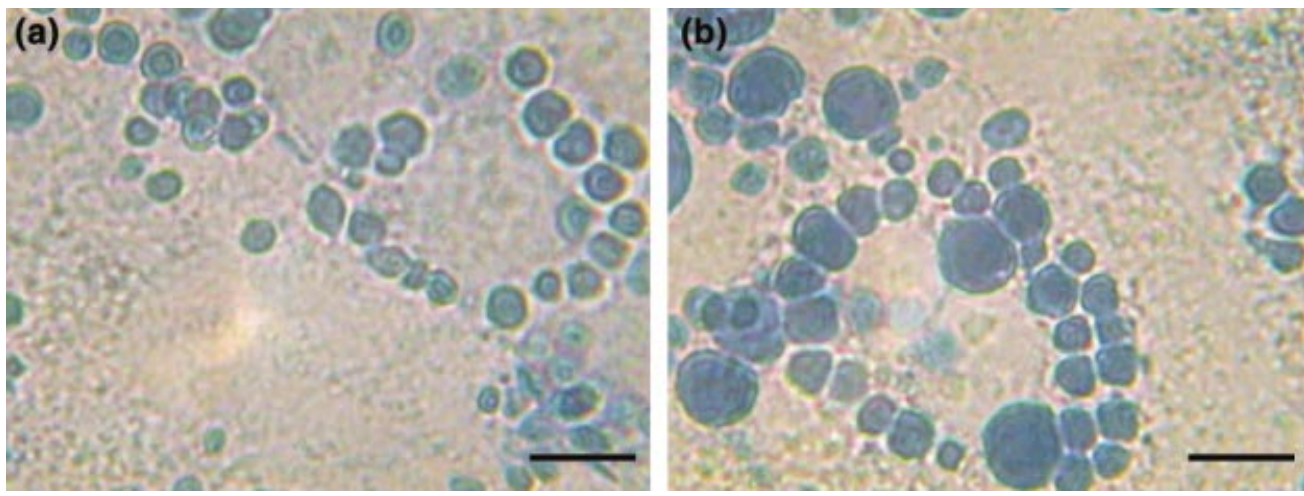

Fig. 1. Choice of culture medium influences embryo composition. Expanding blastocysts stained with Sudan black B to highlight the relative abundance of lipid droplets after culture for 5 days of sheep zygotes in synthetic oviduct fluid (SOF) supplemented with either $0.4 \%(\mathrm{w} / \mathrm{v})$ serum albumin (a) or $10 \%$ $(\mathrm{v} / \mathrm{v})$ serum (b). Although lipid inclusion rates are variable and lack uniformity of distribution even within individual embryos (A. Reis and T. G. McEvoy, unpublished), exposure to serum during culture tends to increase lipid abundance and droplet size. Scale bars represent $10 \mu \mathrm{m}$.

responsive genes are merely fulfilling their intended roles. Instead, at issue here is the induction of changes in other genes, including those that are imprinted during gametogenesis and early embryogenesis. Imprinted genes express only the paternal or the maternal allele and a number of these genes influence fetal size and viability and their epigenetic modification during culture may underlie the phenomenon referred to as large offspring syndrome, which occurs in ruminant (cattle, sheep) species (see Young and Fairburn, 2000; Young et al., 2001). Apparently analogous consequences also have been detected after more invasive manipulations of oocytes or embryos, notably nuclear transfer, but the extent to which the physical intervention and the inevitable in vitro culture component of such procedures are at fault is not yet known. Nevertheless, large offspring syndrome (for reviews, see Kruip and den Daas, 1997; Young et al., 1998; Sinclair et al., 2000) provides emphatic evidence for long-term developmental consequences of domestic animal embryo culture. Epigenetic alterations mediated by non-invasive culture also have been demonstrated in mice after culture of embryos and embryonic stem (ES) cells. For example, Doherty et al. (2000) showed that choice of culture medium for mouse embryos significantly and selectively influences H19 gene expression and DNA methylation in the putative imprinting control domain on the paternal allele.

Consequences of domestic animal embryo culture include aberrations in fetal or placental development in utero (Maxfield et al., 1998; Sinclair et al., 1999; Farin et al., 2000; Peterson et al., 2000) and peri- and post-natal differences (Brown and Radziewic, 1998; McEvoy et al., 1998; van Wagtendonk-de Leeuw et al., 2000). A study of post-natal development of oversized (>60 kg at birth) calves derived in vitro demonstrated that, when killed at 13 months of age, these calves did not outweigh calves with normal birth weights derived in vivo or in vitro but the hearts of oversized calves were abnormally large (McEvoy et al., 1998; Fig. 2). This finding indicates that in vitro effects on developmental programming persisted for more than 1 year after birth and, as with sudden unexplained deaths among lambs derived in vitro (Walker et al., 1996), questions whether offspring conceived in vitro can match the life expectancy and health of those gestated entirely in vivo. In contrast, Sangild et al. (2000) suggested that calves derived from embryos produced in vitro were more mature than control animals with respect to certain perinatal health parameters.

\section{Physical manipulation of embryos and cells}

Physical interventions aimed at revising or copying the genome of a mammalian embryo have been transformed from science fiction into fact. Much of the recent progress has occurred in the UK, with production of gene-targeted sheep via nuclear transfer among the latest advances (McCreath et al., 2000). In response to the remarkable achievements that have demonstrated what is technically possible, additional research is aimed at improving and refining new technologies and, for example, in spermmediated gene transfer, establishing the true feasibility of strategies that have yet to be universally accepted for application to domestic animal species.

Undoubtedly, a series of nuclear transfer studies involving sheep has been responsible for most of the scientific headline news in recent years. These advances have placed the prospect of gene-targeted animal production within reach and, in so doing, offer genuine hope for novel therapies and treatments to combat diseases and genetic defects that have thus far thwarted medical efforts. In view of this valuable prize, it is important that the technologies do not fail because of limitations that, if addressed, can be overcome or at least kept to an acceptably low incidence. These technologies are invasive and therefore have repercussions in terms of subsequent 


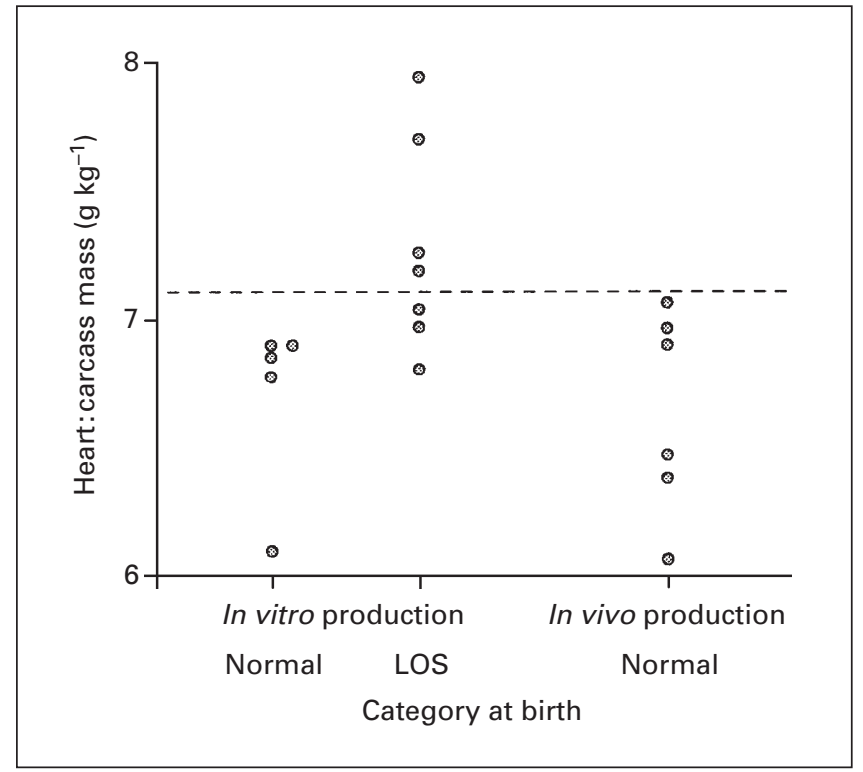

Fig. 2. Postnatal development of cattle from embryos produced in vitro: points represent heart:carcass masses of individual bulls categorized as normal or with large offspring syndrome (LOS). Postnatal legacies of embryo production in vitro include grossly enlarged hearts among 13-month-old Simmental bulls reared from oversize calves (> $60 \mathrm{~kg}$ at birth) derived from embryos produced in vitro. In contrast, the hearts of yearling bulls reared from calves weighing 46-59 $\mathrm{kg}$ at birth were not enlarged, regardless of whether the embryos the dams had received had been produced in vivo or in vitro. Neither size at birth nor embryo origin influenced the carcass masses of these animals, all 18 of which were reared together on ad libitum feedlot diets and killed at the same live weight (redrawn from McEvoy et al., 1998).

survival and development. Much of the remainder of this review will highlight some of the detrimental developmental consequences associated with nuclear and gene transfer technologies and will consider those features of current strategies that are relevant to the problems encountered. However, before considering how physically invasive procedures such as nuclear transfer and gene or sperm injection can have detrimental as well as beneficial consequences, it is important to note that, as in the noninvasive scenarios already considered, in vitro culture per se may contribute to some of the problems that have been encountered. It is perhaps impossible to distinguish the effects of culture from those of physical manipulations undertaken in vitro, but it would be erroneous to presume that conditions in vitro cease to influence cells or embryos that undergo physical manipulations. One question is whether reliance on serum in cloning strategies, for example, to avoid or induce cell quiescence or to support blastocyst production thereafter (Yang et al., 2000), is a safe procedure. It seems incongruous that state-of-the-art nuclear transfer and gene-targeting technologies (for example, see McCreath et al., 2000) rely on a culture constituent that is an ill-defined, inconsistent and pathological fluid (Bavister,
1995). Perhaps some of the adverse consequences of cloning, several of which are analogous to those identified with LOS after serum-supplemented culture of intact embryos (Kruip and den Daas, 1997), are due to the culture of karyoplasts, cytoplasts and reconstituted embryos in the presence of serum. Eggs undergoing the trauma of nuclear transfer might be expected to be more vulnerable to culturemediated developmental aberrations than intact eggs. The same arguments apply, of course, to other manipulations including ES cell-mediated genetic transformations and, albeit to a lesser extent, sperm-mediated gene transfer and intracytoplasmic sperm injection (ICSI). Therefore, it is important to appraise critically those culture procedures used currently to generate karyoplast donor cells, to facilitate physical manipulation and to support subsequent development of reconstituted or otherwise manipulated ova in vitro.

\section{Nuclear transfer - lessons and limitations}

The procedure whereby a cell nucleus (karyoplast) can be introduced into an enucleated oocyte (cytoplast) to generate a new individual whose genetic make-up is determined by the transferred nucleus is remarkable (Fig. 3). In many respects, the wonder is that it ever succeeds. However, knowing that it can occur even when the karyoplast is from adult tissue (Wilmut et al., 1997), the quest is to improve its efficiency and to eliminate incidental abnormalities. Nuclear transfer is not a robust technology in either murine or domestic animal studies and most reconstituted eggs never generate viable offspring. Initial enucleation of the oocyte, via a skilled yet crude excision process, and subsequent introduction of a donor nucleus is the equivalent of major transplant surgery and undoubtedly traumatizes both the cytoplasm and nucleus. Consequently, it may be unreasonable to expect a high survival rate, but it remains to be seen whether the efficiency of generating viable blastocysts, fetuses and offspring can be improved significantly.

As progression from the time of nuclear transfer to the birth of resultant offspring is a multi-stage process, it is difficult to predict how efficiently mouse, cattle or sheep clones can be produced. For example, sometimes only a selected cohort of surviving embryos is transferred, as in the study by Wells et al. (1999), with the possibility of the outcome thereby exaggerating the overall efficiency relative to studies in which all surviving embryos are transferred. Of course, selection of cloned embryos at the blastocyst stage is a valid strategy which, in terms of surrogate recipient requirements, facilitates efficient generation of offspring. Selection stringency at egg transfer undoubtedly differs across species and laboratories, but the survival of those eggs that are placed into a receptive uterine environment nevertheless provides insights into the developmental competence and normality of embryos generated by nuclear transfer. Evidence from most nuclear transfer studies indicates that losses during pregnancy and at or soon after birth are considerable, with a range of 
(a)

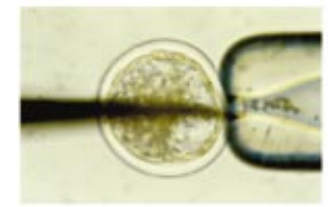

Embryo bisection
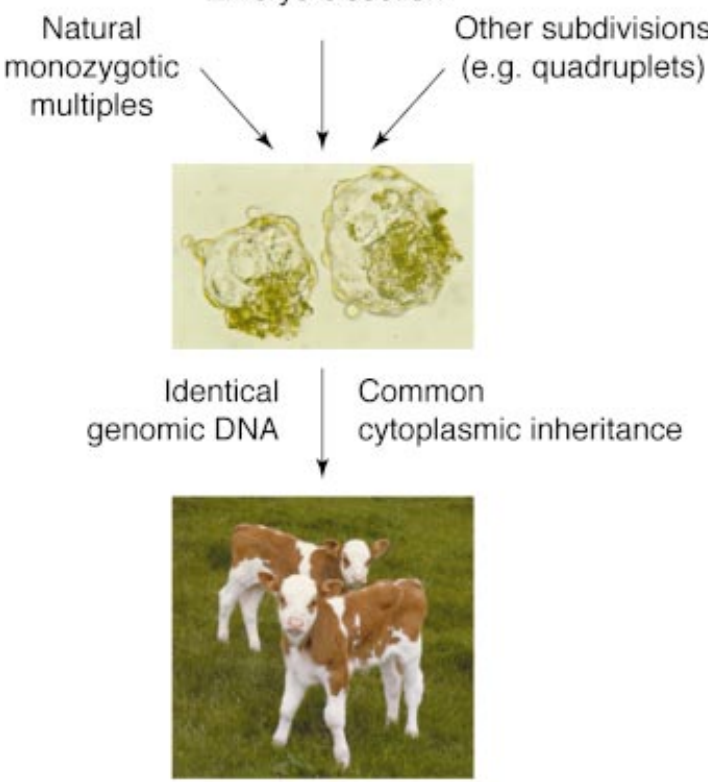

True clones (b) Enucleated oocytes - each with distinct mtDNA
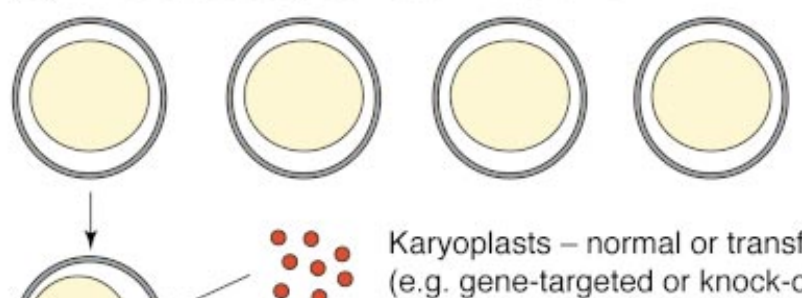

Karyoplasts - normal or transformed (e.g. gene-targeted or knock-outs)

Nuclear transfer to enucleated oocyte (cytoplast)

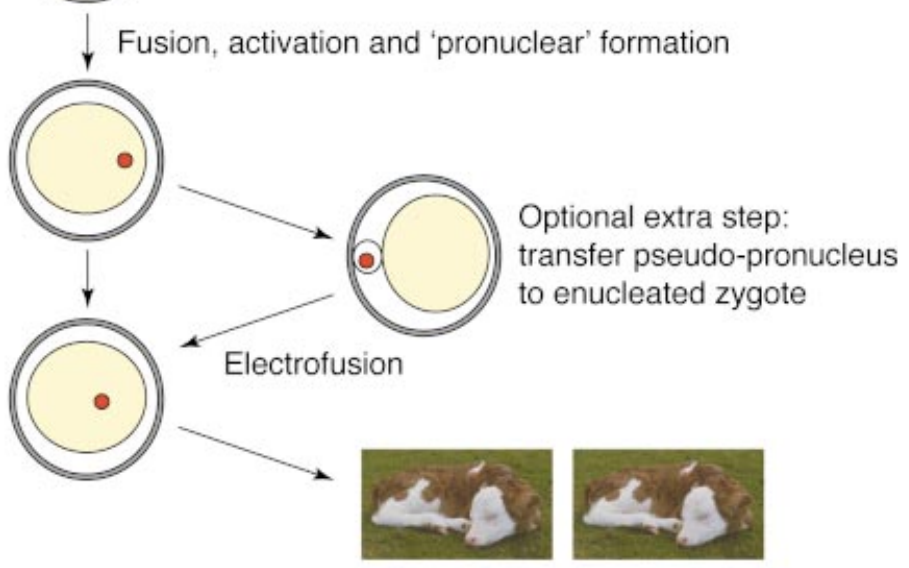

Genomic copies

Fig. 3. Production of clones and genomic copies in calves. As well as the natural occurrence of monozygotic twin or multiple offspring, simple bisection or further subdivision of domestic animal embryos can be used to produce limited numbers of true, genetically identical clones (a). Alternative procedures, using nuclear transfer technologies (b) generate individuals that share identical or near-identical nuclear DNA but these differ in respect of their cytoplasmic mitochondrial DNA (mtDNA) inheritance. Hence, as noted by Campbell (1999), these animals are more properly described as 'genomic copies' than as definitive clones.

abnormalities contributing to this wastage (cattle: Kruip and den Daas, 1997; Cibelli et al., 1998; Wells et al., 1999; Hill et al., 2000; sheep: Wells et al., 1997; De Sousa et al., 2000; and mice: Wakayama et al., 1998). Kato et al. (1998) cited the loss of four of eight calves cloned from somatic cells but these losses were attributed to perinatal complications rather than to any developmental abnormalities. The authors indicated that signs of labour and mammary development were subdued in most dams in this study, a feature also noted in some calvings after transfer of intact embryos produced in vitro (see Sinclair et al., 2000). Mortality has also been reported some time after calving, notably in a cloned calf derived from tissue taken from a donor that was itself a clone (Renard et al., 1999). In this study, post-natal echocardiography indicated the presence of an enlarged right ventricle, but death at day 51 was due to severe anaemia, and postmortem examination revealed lymphoid hypoplasia and thymic atrophy. The authors concluded that the defect was attributable to epigenetic events during reprogramming of the reconstructed embryo and expressed confidence in their in vitro system, which had already facilitated the generation of $>100$ healthy calves via nuclear transfer. In the targeted gene transfer study of McCreath et al. (2000), of 14 lambs born alive, seven died within 2 days and four more died within 3 months. Abnormalities included a high incidence of kidney defects and brain and liver pathologies and were similar to those reported after nuclear transfer involving the same cells (Schnieke et al., 1997), leading the authors to conclude that they were probably due to some feature of cell treatment or nuclear transfer rather than to gene targeting per se.

One factor that influences the efficiency of nuclear transfer and normality of resultant offspring is the choice of cells for provision of donor nuclei. Renard (1998) noted that late abortions and neonatal deaths in cattle were more frequent after nuclear transfer of somatic nuclei than after nuclear transfer of embryonic nuclei, indicating that karyoplast origin may influence the extent of deviant development in clones. In choosing cells for cloning of domestic animals or mice, decisions may be constrained by end-use considerations as much as by the resilience or age of potential donor cells. In particular, genetically 
transformed cells may be most valuable in domestic species with gene knockouts perhaps a priority in mice. Kato et al. (1998) noted that it may be preferable to use cells from a proven adult, for example, in respect of milk yield, than cells from a genetically elite but untried embryonic or fetal source. Among adult-derived tissues that have been used, cumulus or granulosa cells have generated promising results. Wells et al. (1999) found that nuclear transfer with cultured granulosa cells generated ten calves, all of which survived, although development of re-cloned fetuses did not extend beyond 100 days of gestation. In contrast, mice have been cloned sequentially by the transfer of adult cumulus cell nuclei without any adverse effects (Wakayama et al., 1998). In a novel two-stage procedure, pigs free of developmental and health defects were generated from granulosa cell-derived karyoplasts (Polejaeva et al., 2000). In reporting that nuclear transfer using cumulus cells as donor nuclei generated a $49 \%$ blastocyst yield compared with a $23 \%$ efficiency when oviductal cells were used, Kato et al. (1998) proposed some possible advantages to be gained from use of cumulus cells as donor nuclei. In addition to citing the potential of cumulus cells to interact compatibly with oocyte cytoplasm in vivo, the authors also noted the possibility that cumulus cell populations are protected from ageing. This latter argument is based on evidence of telomerase activity in human cumulus cells (Dorland et al., 1997), and raises a significant issue concerning the consequences of generating offspring from nuclear transfer procedures that use adult donor nuclei.

In somatic cells, ageing is accompanied by progressive telomere shortening owing to incomplete replication of terminal sequences of double-stranded DNA; when telomeres become critically shortened, replicative senescence may result through the action of cell cycle checkpoints (Stampfer et al., 1997). In contrast, in situations in which cell ageing is to be avoided, a facility to restore telomere length is achieved by telomerase activity. Therefore, it might be argued that cells with such capability are more suitable sources of karyoplasts for nuclear transfer than ageing cell populations if telomere shortening cannot be reversed during nuclear transfer. In this context, ewe 6 LL3 (Dolly) took the lead as a candidate for scrutiny of ageing effects. Analysis of terminal restriction fragment (TRF) length, a proxy for telomere size, in 6LL3 and in other cloned sheep was carried out and compared with TRF length data from relevant cell populations (Shiels et al., 1999a). The results demonstrated that TRF lengths in cells from Dolly were consistent with her being derived from transfer of a nucleus from a cell of a 6-year-old adult, with TRF lengths of other animals reflecting their derivation from younger nuclear material. Shiels et al. (1999a) noted that, despite the evidence of apparent telomere shortening, Dolly had not demonstrated any adverse health effects or evidence of premature physiological ageing. Dolly has given birth three times and it is reassuring that the TRF length of her first offspring was consistent with age-matched lambs rather than reflecting the limitations of its dam (Shiels et al., 1999b). Elsewhere, Lanza et al. (2000) reported that transfer of senescent donor nuclei resulted in the birth of six healthy cloned calves and, moreover, that telomere length in nucleated blood cells was restored and even extended, relative to newborn and age-matched controls. Gene expression data for dermal fibroblast cells from these animals were consistent with this finding. The same report also provided evidence of a $50 \%$ greater proliferative lifespan among fetal clone-derived fibroblast cells than equivalent control cells in vitro, echoing similar findings from another cattle study by Cibelli et al. (1998). In contrast, Betts et al. (2001) did not detect any evidence of extended telomere lengths in tissues of their cloned calves and suggested that an activated immune response played a role in the telomere-lengthening scenario reported by Lanza et al. (2000).

The effectiveness and efficiency of nuclear transfer depends on a range of other factors beyond the scope of this review. Among the topics that need to be taken into account are quiescence of donor nuclei, strategies for cytoplast production, and oocyte activation (Wakayama et al., 1998; Campbell, 1999; Dominko et al., 1999; Kishikawa et al., 1999; Polejaeva and Campbell, 2000). Differentiation status of successful karyoplasts should also be considered. In this context, Dorland et al. (1997) suggested that stem cells may be present in human cumulus cell populations, a possibility that also applies to other tissues (Wilmut, 1999). Ultimately, ongoing refinement of the overall process, including avoidance of hazards of culture in vitro referred to previously, should help to eliminate many of the inefficiencies and aberrant developmental features associated with production of cloned offspring. In support of this contention, Polejaeva et al. (2000) reported the successful cloning of pigs using a strategy of minimal in vitro and, in most steps, serum-free culture. In this study, none of the five offspring born was abnormal or unhealthy although, because the nuclear transfer process also differed from earlier procedures in other respects, the extent to which better piglet vitality was due to more appropriate culture is not known.

In a study indicative of the long-term impact of cloning on animal production, Tamashiro et al. (2000) reported that nuclear transfer of adult somatic cell nuclei to produce cloned mice may delay some developmental milestones but does not adversely compromise postnatal behaviour. A curious feature of the cloned mice in this study was that their body weights were increased significantly after birth. Wakayama et al. (1998) reported that clones and cloned clones were produced with comparable efficiency, leading them to conclude that successive generations do not undergo changes that influence the outcome of the cloning process.

\section{Gene transfer technologies}

In a review of transgenic domestic livestock production, Ward and Brown (1998) highlighted the achievements and limitations of preceding years and concluded that nuclear 

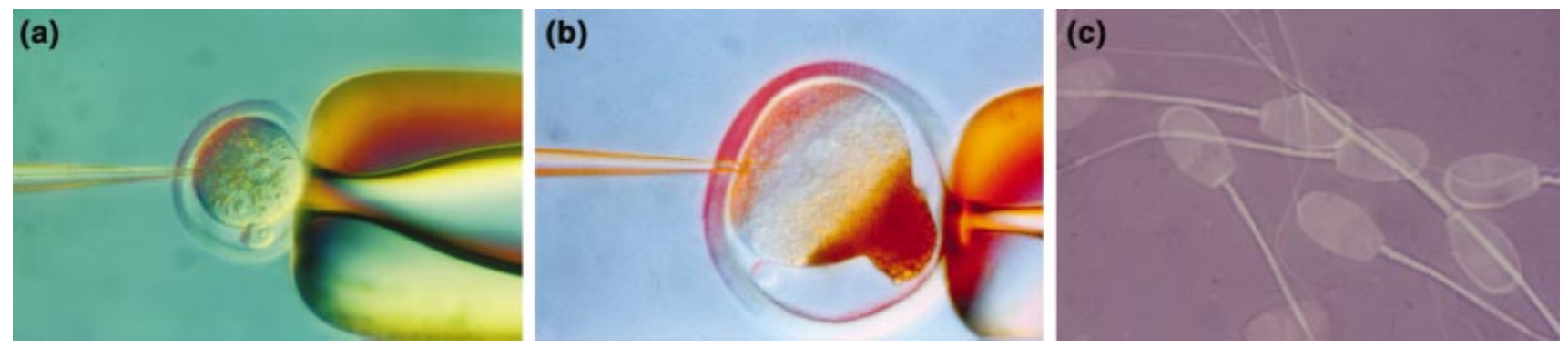

Fig. 4. Gene transfer technologies. Production of transgenic animals via pronuclear injection of mouse (a) or cattle (b) zygotes has low efficiency and is likely to be superseded by nuclear transfer of genetically transformed karyoplasts, a process that facilitates the production of gene-targeted animals. Alternative strategies remain elusive, but some researchers believe that individual spermatozoa (c) may yet prove useful as carriers of large constructs or artificial chromosomes.

transfer was required to bolster the capabilities for genetic transformation of farm animal species. In particular, they argued, nuclear transfer would facilitate testing of novel gene constructs, largely because of the greatly increased likelihood of generating transgenic offspring. Nuclear transfer should also help overcome the inefficiency of microinjection, which is a major obstacle to effective application of gene transfer technology in domestic animal species, especially in the context of agricultural production (Murray, 1999; Brink et al., 2000).

Before the landmark study of McCreath et al. (2000), the production of transgenic but non-targeted animals via nuclear transfer in sheep (Schnieke et al., 1997), cattle (Cibelli et al., 1998) and goats (Baguisi et al., 1999) was reported. Therefore, it is reasonable to expect that much future research relating to gene transfer in domestic livestock will be hand-in-glove with cloning technology. Consequently, many of the hazards and limitations will be those already described for nuclear transfer and culture in vitro. However, some additional steps merit careful consideration, among them the in vitro screening process required to identify suitably transformed cells before selection of karyoplasts. Gene constructs are designed to ensure that the gene of interest is co-integrated with a 'marker' gene, frequently one that confers antibiotic resistance, so that only appropriately transformed cells should survive an antibiotic challenge. However, it is important to ensure that, firstly, the antibiotic challenge does not induce undesirable alterations among surviving cells intended for nuclear transfer and, secondly, that the antibiotic resistance component of the inserted gene construct does not compromise the health of resultant offspring. Similar considerations also apply to alternative marker genes, including those for firefly luciferase, green fluorescent protein (GFP) and enhanced GFP (EGFP). Expression of such genes is readily detectable, making them valuable research tools that promise to enhance efficiency of gene transfer (Menck et al., 1998; Guttierez-Adan and Pintado, 2000; Hadjantonakis and Nagy, 2000), although the risk of mutagenic or toxic effects, and of exposure to ultraviolet excitation light, must be appreciated (Kato et al.,
1999; Perry et al., 1999). In addition, there is a genuine risk that, however useful fluorescent animals might be, their profoundly unnatural appearance may generate adverse public reaction. In addition to such eye-catching features, more apparently mundane aspects of transgenic technology also can influence embryo survival after gene microinjection. For example, Wall et al. (2000) demonstrated that choice of either of two DNA purification methods influenced embryo survival and pregnancy rate in both mice and sheep, without altering transgene integration rate. Likewise, improvements in gene constructs have meant that some of the extreme consequences associated with the early gene transfer studies in farm animals are now avoidable (see Murray, 1999). Murray (1999) noted that insufficient attention has been paid to anticipating problems that might arise in respect of transgene introgression into populations with different genetic backgrounds.

Although genetic transformation via nuclear transfer promises to supersede or at least complement conventional gene injection procedures, some other strategies, including sperm-mediated gene transfer and ICSI, also merit consideration (Fig. 4). Sperm-mediated gene transfer has had a chequered history and, as noted by Gandolfi (2000), opinion remains divided over claims that genuinely transgenic offspring have been born. Among the many reports, which refer to honey bees, fish species and chickens as well as mice and domestic animals, one report at least has demonstrated transgene transmission to the $F_{1}$ generation. In that study, sperm-mediated gene transfer was achieved via an ICSI procedure that involved co-injection of 'killed' spermatozoa with an EGFP gene construct into the cytoplasm of mouse oocytes (Perry et al., 1999). The success of transgene integration was probably due to the fact that sperm membranes were sufficiently disrupted to bind exogenous DNA that subsequently, and thus far inexplicably, survived degradation within the oocyte to become incorporated into the genome of the resultant zygote. Thereafter, the EGFP transgene was transmitted to $\mathrm{F}_{1}$ offspring, which expressed it in a manner consistent with Mendelian inheritance of a single gene locus. Perry et al. (1999) observed that among the advantages of ICSI and 
sperm-mediated gene transfer is a capacity to cope with large constructs or artificial chromosomes and perhaps to ensure additional sperm-associated protection of constructs. These authors also advocated ICSI as a more 'userfriendly option' than pronuclear microinjection in the opaque lipid-dense eggs of cattle and pigs. The first report of ICSI in cattle involved the use of 'dead' spermatozoa (Goto et al., 1990) and more recent investigations have demonstrated not only that bovine male pronuclear formation rates differ from those obtained via in vitro fertilization but also that, unlike in mouse ICSI, there is a requirement for chemical pretreatment of the spermatozoa (Wei and Fukui, 1999).

\section{Conclusions}

In recent years, embryo manipulation technologies in vitro have developed to a stage where targeting of precise genetic modifications, already a valuable research tool in mice, is a realistic prospect in farm animal species. Although the technology is still in its infancy (Piedrahita, 2000), successful gene-targeted sheep production represents not only a major advance beyond alternative strategies for gene transfer, notably pronuclear gene-injection, but also a fulfilment of the promise offered by nuclear transfer technology, which was itself made possible by earlier but less spectacular advances in embryo and cell culture. However, it is possible that we will only capitalize fully on the ever more sophisticated nuclear transfer and gene targeting technologies when unspectacular refinements to in vitro culture systems finally establish an environment that is hazard-free and that avoids perturbing the early regulation of mammalian development. Having already demonstrated what is possible, scientists must now realize that application of recent and remarkable research advances for the benefit of animal and human health will hereafter depend on minimizing, and preferably eliminating, adverse consequences arising from in vitro manipulation of animal cells and embryos. Future research must focus on strategies that help to achieve this, thereby safeguarding offspring and their progeny as well as ensuring that benefits accrue at acceptable costs. Otherwise, promising biotechnologies will fail to fulfil their potential.

The Scottish Agricultural College receives funding from the Scottish Executive Rural Affairs Department. Large offspring studies are funded by the Ministry of Agriculture, Fisheries and Food and have been carried out in collaboration with colleagues at Roslin Institute (Edinburgh) and the Rowett Research Institute (Aberdeen).

\section{References}

Key references are identified by asterisks.

Abe H, Otoi T, Tachikawa S, Yamashita S, Satoh T and Hoshi H (1999a) Fine structure of bovine morulae and blastocysts in vivo and in vitro. Anatomy and Embryology (Berlin) 199 519-527

Abe H, Yamashita S, Itoh T, Satoh T and Hoshi H (1999b) Ultrastructure of bovine embryos developed from in vitro-matured and -fertilized oocytes: comparative morphological evaluation of embryos cultured either in serum-free medium or in serum-supplemented medium Molecular Reproduction and Development 53 325-335

Allan GJ, Flint DJ and Patel K (2001) The insulin-like growth factor (IGF) axis during embryonic development Reproduction 122 31-39

Baguisi A, Behboodi E, Melican DT et al. (1999) Production of goats by somatic cell nuclear transfer Nature Biotechnology 17 456-461

Barnett DK and Bavister BD (1996) What is the relationship between the metabolism of preimplantation embryos and their developmental competence? Molecular Reproduction and Development 43 105-133

Bavister BD (1995) Culture of preimplantation embryos: facts and artifacts Human Reproduction Update 191-148

Betts DH, Bordignon V, Hill JR, Winger Q, Westhusin ME, Smith LC and King WA (2001) Reprogramming of telomerase activity and rebuilding of telomere length in cloned cattle Proceedings of the National Academy of Sciences USA 98 1077-1082

Brink MF, Bishop MD and Pieper FR (2000) Developing efficient strategies for the generation of transgenic cattle which produce biopharmaceuticals in milk Theriogenology 53 139-148

Brown BW and Radziewic T (1998) Production of sheep embryos in vitro and development of progeny following single and twin embryo transfers Theriogenology 49 1525-1536

Byrne AT, Southgate J, Brison DR and Leese HJ (1999) Analysis of apoptosis in the preimplantation bovine embryo using TUNEL Journal of Reproduction and Fertility 117 97-105

*Campbell KHS (1999) Nuclear equivalence, nuclear transfer, and the cell cycle Cloning 1 3-15

Cibelli JB, Stice SL, Golueke PJ, Kane JJ, Jerry J, Blackwell C, Ponce de Leon FA and Robl JM (1998) Cloned transgenic calves produced from nonquiescent fetal fibroblasts Science $\mathbf{2 8 0} 1256-1258$

Crosier AE, Farin PW, Dykstra MJ, Alexander JE and Farin CE (2000) Ultrastructural morphometry of bovine compact morulae produced in vivo or in vitro. Biology of Reproduction 62 1459-1465

De Sousa PA, Walker S, King TJ, Young LE, Harkness L, Ritchie WA, Travers A, Ferrier P and Wilmut I (2000) Evaluation of gestational deficiencies in cloned sheep Theriogenology 53214

Doherty AS, Mann MRW, Tremblay KD, Bartolomei MS and Schultz RM (2000) Differential effects of culture on imprinted $\mathrm{H} 19$ expression in the preimplantation mouse embryo Biology of Reproduction 62 1526-1535

Dominko T, Ramalho-Santos J, Chan A, Moreno RD, Luetjens CM, Simerly C, Hewitson L, Takahashi D, Martinovich C, White JM and Schatten G (1999) Optimization strategies for production of mammalian embryos by nuclear transfer Cloning $\mathbf{1} 143-152$

Dorland M, Gardner DK and Trounson AO (1994) Serum in synthetic oviduct fluid causes mitochondrial degeneration in ovine embryos Journal of Reproduction and Fertility Abstract Series 1325

Dorland M, Hol S, van Kooij RJ and te Velde ER (1997) Telomerase in human cumulus cells Journal of Reproduction and Fertility Abstract Series 2031

Eckert J, Pugh PA, Thompson JG, Niemann H and Tervit HR (1998) Exogenous protein affects developmental competence and metabolic activity of bovine pre-implantation embryos in vitro. Reproduction Fertility and Development 10 327-332

Farin PW, Stockburger EM, Rodriguez KF, Crosier AE, Blondin P, Alexander JE and Farin CE (2000) Placental morphology following transfer of bovine embryos produced in vivo or in vitro. Theriogenology 53474

Ferguson EM and Leese HJ (1999) Triglyceride content of bovine oocytes and early embryos Journal of Reproduction and Fertility 116 373-378

Fleming JV, Fontanier N, Harries DN and Rees WD (1997) The growth arrest genes gas5, gas6, and CHOP-10 (gadd153) are expressed in the mouse preimplantation embryo Molecular Reproduction and Development 48 310-316

Fontanier-Razzaq NC, Hay SM and Rees WD (1999) Upregulation of CHOP-10 (gadd153) expression in the mouse blastocyst as a response to stress Molecular Reproduction and Development 54 326-332

Fontanier-Razzaq NC, McEvoy TG, Robinson JJ and Rees WD (2001) DNA damaging agents increase gadd153 (CHOP-10) messenger RNA levels in bovine preimplantation embryos cultured in vitro. Biology of Reproduction 64 1386-1391 
Gandolfi F (2000) Sperm-mediated transgenesis Theriogenology $\mathbf{5 3}$ $127-137$

Goto K, Kinoshida A, Takuma Y and Ogawa K (1990) Fertilization of bovine oocytes by the injection of immobilised, killed spermatozoa Veterinary Record 127 517-520

Guttierez-Adan A and Pintado B (2000) Effect of flanking matrix attachment regions on the expression of microinjected transgenes during preimplantation development of mouse embryos Transgenic Research 9 81-89

Hadjantonakis AK and Nagy A (2000) FACS for the isolation of individual cells from transgenic mice harboring a fluorescent protein reporter Genesis 27 95-98

Hardy K (1999) Apoptosis in the human embryo Reviews of Reproduction 4 125-134

Harvey MB, Arcellana-Panlilio MY, Zhang X, Schultz GA and Watson AJ (1995) Expression of genes encoding antioxidant enzymes in preimplantation mouse and cow embryos and primary bovine oviduct cultures employed for embryo coculture Biology of Reproduction 53 $532-540$

Hill JR, Long CR, Looney CR, Winger QA, Spencer TE, Bazer FW, Burghardt RC and Westhusin ME (2000) Placental abnormalities in first trimester somatic cell cloned fetuses Theriogenology 53218

Ho Y, Wigglesworth K, Eppig JJ and Schultz RM (1995) Preimplantation development of mouse embryos in KSOM: augmentation by amino acids and analysis of gene expression Molecular Reproduction and Development 41 232-238

Holm P and Callesen H (1998) In vivo versus in vitro produced bovine ova: similarities and differences relevant for practical application Proceedings of the 14th Scientific Meeting of the European Embryo Transfer Association (AETE), 11-12 September, Venice, pp 65-79

Hyttel P, Laurincik J, Viuff D et al. (2000a) Activation of ribosomal RNA genes in preimplantation cattle and swine embryos Animal Reproduction Science 60-61 49-60

Hyttel P, Laurincik J, Rath D, Rosenkranz C, Schellander K, Ochs RL and Niemann H (2000b) Aberrations in ribosomal RNA gene activation in in vitro-produced porcine embryos Theriogenology 53358

James RM, Klerkx AHEM, Keighren M, Flockhart JH and West JD (1995) Restricted distribution of tetraploid cells in mouse tetraploid-diploid chimaeras Developmental Biology $167213-226$

Jurisicova A, Rogers I, Fasciani A, Casper RF and Varmuza S (1998) Effect of maternal age and conditions of fertilization on programmed cell death during murine preimplantation embryo development Molecular Human Reproduction 4 139-145

Kato Y, Tani T, Sotomaru Y, Kurokawa K, Kato J-y, Doguchi H, Yasue H and Tsunoda Y (1998) Eight calves cloned from somatic cells of a single adult Science 282 2095-2098

Kato M, Yamanouchi K, Ikawa M, Okabe M, Naito K and Tojo H (1999) Efficient selection of transgenic mouse embryos using EGFP as a marker gene Molecular Reproduction and Development 54 43-48

Khosla S, Dean W, Brown D, Reik W and Feil R (2001) Culture of preimplantation mouse embryos affects fetal development and the expression of imprinted genes Biology of Reproduction 64 918-926

King KL and Cidlowski JA (1998) Cell cycle regulation and apoptosis Annual Reviews of Physiology 60 601-617

Kishikawa H, Wakayama T and Yanagimachi R (1999) Comparison of oocyte-activating agents for mouse cloning Cloning 1 153-159

Krisher RL and Bavister BD (1998) Responses of oocytes and embryos to the culture environment Theriogenology 49 103-114

Krisher RL, Lane M and Bavister BD (1999) Developmental competence and metabolism of bovine embryos cultured in semi-defined and defined culture media Biology of Reproduction 60 1345-1352

Kruip ThAM and den Daas JHG (1997) In vitro produced and cloned embryos: effects on pregnancy, parturition and offspring Theriogenology 47 43-52

Kubisch HM, Larson MA, Ealy AD, Murphy CN and Roberts RM (2001) Genetic and environmental determinants of interferon $\tau$ secretion by in vivo- and in vitro-derived bovine blastocysts Animal Reproduction Science 66 1-13

Lanza RP, Cibelli JB, Blackwell C et al. (2000) Extension of cell life-span and telomere length in animals cloned from senescent somatic cells Science 288 665-669

Laurincik J, Thomsen PD, Hay-Schmidt A, Avery B, Greve T, Ochs RL and Hyttel P (2000) Nucleolar proteins and nuclear ultrastructure in preimplantation bovine embryos produced in vitro. Biology of Reproduction 62 1024-1032

Leese HJ, Donnay I and Thompson JG (1998) Human assisted conception: a cautionary tale. Lessons from domestic animals Human Reproduction 13 (Supplement 4) 184-202

*McCreath KJ, Howcroft J, Campbell KH, Colman A, Schnieke AE and Kind A) (2000) Production of gene-targeted sheep by nuclear transfer from cultured somatic cells Nature 405 1066-1069

McEvoy TG, Sinclair KD, Broadbent PJ, Goodhand KL and Robinson JJ (1998) Post-natal growth and development of Simmental calves derived from in vivo or in vitro embryos Reproduction, Fertility and Development $10459-464$

McEvoy TG, Sinclair KD, Young LE, Wilmut I and Robinson JJ (2000a) Large offspring syndrome and other consequences of ruminant embryo culture in vitro: relevance to blastocyst culture in human ART Human Fertility 3 238-246

McEvoy TG, Coull GD, Broadbent PJ, Hutchinson JSM and Speake BK (2000b) Fatty acid composition of lipids in immature cattle, pig and sheep oocytes with intact zona pellucida Journal of Reproduction and Fertility 118 163-170

Maxfield EK, Sinclair KD, Broadbent PJ, McEvoy TG, Robinson JJ and Maltin CA (1998) Short-term culture of ovine embryos modifies fetal myogenesis American Journal of Physiology 274 (Endocrinology and Metabolism 37) E1121-E1123

Menck M, Mercier Y, Campion E, Lobo RB, Heyman Y, Renard JP and Thompson EM (1998) Prediction of transgene integration by noninvasive bioluminescent screening of microinjected bovine embryos Transgenic Research 7 331-341

Murray JD (1999) Genetic modification of animals in the next century Theriogenology 51 149-159

Nasr-Esfahani MH, Aitken JR and Johnson MH (1990) Hydrogen peroxide levels in mouse oocytes and early cleavage stage embryos developed in vitro or in vivo. Development 109 501-507

Niemann H and Wrenzycki C (2000) Alterations of expression of developmentally important genes in preimplantation bovine embryos by in vitro culture conditions: implications for subsequent development Theriogenology 53 21-34

Pangestu M, Lewis I and Shaw J (1996) Alpha tocopherol microinjection protects in vitro-produced bovine pronuclear-stage embryos from chilland cryo-injury. In Proceedings of the 13th International Congress on Animal Reproduction Sydney Vol. 3 pp 15-17

Perry AC, Wakayama T, Kishikawa H, Kasai T, Okabe M, Toyoda $\mathrm{Y}$ and Yanagimachi R (1999) Mammalian transgenesis by intracytoplasmic sperm injection Science $\mathbf{2 8 4}$ 1180-1183

Peterson AJ, McMillan WH and Thompson JG (2000) Various allantoic pathologies are associated with malformation of allantoic development of the IVP bovine embryo Proceedings of the 14th International Congress on Animal Reproduction, 2-6 July Stockholm, Abstracts Vol. 1, Paper 5:6

Piedrahita JA (2000) Targeted modification of the domestic animal genome Theriogenology 53 105-116

Polejaeva IA and Campbell KHS (2000) New advances in somatic cell nuclear transfer: applications in transgenesis Theriogenology $\mathbf{5 3}$ $117-126$

Polejaeva IA, Chen S-H, Vaught TD et al. (2000) Cloned pigs produced by nuclear transfer from adult somatic cells Nature 407 86-90

Pollard JW and Leibo SP (1994) Chilling sensitivity of mammalian embryos Theriogenology 41 101-106

Renard JP (1998) Chromatin remodelling and nuclear reprogramming at the onset of embryonic development in mammals Reproduction, Fertility and Development 10 573-580

Renard JP, Chastant S, Chesne P, Richard C, Marchal J, Cordonnier N, Chavatte P and Vignon X (1999) Lymphoid hypoplasia and somatic cloning Lancet 353 1489-1491

Sangild PT, Schmidt M, Jacobsen H, Fowden AL, Forhead A, Avery B and 
Greve T (2000) Blood chemistry, nutrient metabolism, and organ weights in fetal and newborn calves derived from in vitro-produced bovine embryos Biology of Reproduction 62 1495-1504

Schnieke AE, Kind AJ, Ritchie WA, Mycock K, Scott AR, Ritchie M, Wilmut I, Colman A and Campbell KHS (1997) Human factor IX transgenic sheep produced by transfer of nuclei from transfected fetal fibroblasts Science 278 2130-2133

Shiels PG, Kind AJ, Campbell KHS, Waddington D, Wilmut I, Colman A and Schnieke AE (1999a) Analysis of telomere lengths in cloned sheep Nature 399 316-317

Shiels PG, Kind AJ, Campbell KHS, Wilmut I, Waddington D, Colman A and Schnieke AE (1999b) Analysis of telomere length in Dolly, a sheep derived by nuclear transfer Cloning 1 119-125

Sinclair KD, McEvoy TG, Maxfield EK, Maltin CA, Young LE, Wilmut I, Broadbent PJ and Robinson JJ (1999) Aberrant fetal growth and development after in vitro culture of sheep zygotes Journal of Reproduction and Fertility 116 177-186

* Sinclair KD, Young LE, Wilmut I and McEvoy TG (2000) In utero overgrowth in ruminants following embryo culture: lessons from mice and a warning to men Human Reproduction 15 (Supplement 5) 68-86

Smith LC, Bordignon V, Garcia JM and Meirelles FV (2000) Mitochondrial genotype segregation and effects during mammalian development: applications to biotechnology Theriogenology 53 35-46

Stampfer MR, Bodnar A, Garbe J, Wong M, Pan A, Villeponteau B and Yaswen P (1997) Gradual phenotypic conversion associated with immortalization of cultured human mammary epithelial cells Molecular Biology of the Cell 8 2391-2405

Tamashiro KLK, Wakayama T, Blanchard RJ, Blanchard DC and Yanagimachi R (2000) Postnatal growth and behavioral development of mice cloned from adult cumulus cells Biology of Reproduction $\mathbf{6 3}$ 328-334

Thompson JG (1996) Improving the requirements for bovine embryo culture Theriogenology 45 27-40

Thompson JG (1997) Comparison between in vivo-derived and in vitroproduced pre-elongation embryos from domestic ruminants Reproduction, Fertility and Development $9341-354$

Thompson JG, Gardner DK, Pugh PA, McMillan WH and Tervit HR (1995) Lamb birth weight is affected by culture system utilized during in vitro pre-elongation development of ovine embryos Biology of Reproduction 53 1385-1391

Thompson JG, Sherman AN, Allen NW, McGowan LT and Tervit HR (1998) Total protein content and protein synthesis within pre-elongation stage bovine embryos Molecular Reproduction and Development $\mathbf{5 0}$ 139-145

Van Langendonckt A, Morales H, Massip A and Dessy F (1998) Effect of hydrogen peroxide on in vitro development of bovine embryos Theriogenology 49221

van Wagtendonk-de Leeuw AM, Mullaart E, de Roos APW, Merton JS, den Daas JHG, Kemp B and de Ruigh L (2000) Effects of different reproduction techniques: $\mathrm{AI}, \mathrm{MOET}$ or IVP, on health and welfare of bovine offspring Theriogenology 53 579-597

Viuff D, Rickords L, Offenberg H, Hyttel P, Avery B, Greve T, Olsaker I, Williams JL, Callesen H and Thomsen PD (1999) A high proportion of bovine blastocysts produced in vitro are mixoploid Biology of Reproduction $601273-1278$

Wakayama T, Perry ACF, Zuccotti M, Johnson KR and Yanagimachi R
(1998) Full-term development of mice from enucleated oocytes injected with cumulus cell nuclei Nature 394 369-374

Walker SK, Heard TM and Seamark RF (1992) In vitro culture of sheep embryos without co-culture: successes and perspectives Theriogenology 37 111-126

Walker SK, Hartwich KM and Seamark RF (1996) The production of unusually large offspring following embryo manipulation: concepts and challenges Theriogenology 45 111-120

Walker SK, Hartwich KM, Robinson JS and Seamark RF (1998) Influence of in vitro culture of embryos on the normality of development. In Gametes: Development and Function pp 457-484 Eds A Lauria et al. Serono Symposia, Tabloid S.r.I., Rome

Wall RJ, Paleyanda RK, Foster JA, Powell A, Rexroad C and Lubon H (2000) DNA preparation method can influence outcome of transgenic animal experiments Animal Biotechnology 11 19-32

Ward KA and Brown BW (1998) The production of transgenic domestic livestock: successes, failures and the need for nuclear transfer Reproduction, Fertility and Development 10 659-665

Watson AJ, Westhusin ME, De Sousa PA, Betts DH and Barcroft LC (1999) Gene expression regulating blastocyst formation Theriogenology $\mathbf{5 1}$ 117-133

Wei $\mathbf{H}$ and Fukui $\mathbf{Y}$ (1999) Effects of bull, sperm type and sperm pretreatment on male pronuclear formation after intracytoplasmic sperm injection in cattle Reproduction, Fertility and Development 11 59-65

Wells DN, Misica PM, Day AM and Tervit HR (1997) Production of cloned lambs from an established embryonic cell line: a comparison between in vivo- and in vitro-matured cytoplasts Biology of Reproduction 57 385-393

Wells DN, Misica PM and Tervit HR (1999) Production of cloned calves following nuclear transfer with cultured adult mural granulosa cells Biology of Reproduction 60 996-1005

Willadsen SM, Janzen RE, McAlister RJ, Shea BF, Hamilton G and McDermand D (1991) The viability of late morulae and blastocysts produced by nuclear transplantation in cattle Theriogenology 35 $161-170$

Wilmut I (1999) Differentiation potential Cloning 1 131-132

*Wilmut I, Schnieke A, McWhir J, Kind A and Campbell KHS (1997) Viable offspring derived from fetal and adult mammalian cells Nature 385 $810-813$

Wrenzycki C, Herrmann D, Carnwath JW and Niemann H (1999) Alterations in the relative abundance of gene transcripts in preimplantation bovine embryos cultured in medium supplemented with either serum or PVA Molecular Reproduction and Development 53 8-18

Yang BS, Im GS, Park SJ, Chang WK and Park CS (2000) Effect of protein supplementation on the in vitro development of embryos produced by cumulus cell nuclear transfer in Korean native Hanwoo cattle Theriogenology 53246

*Young LE and Fairburn HR (2000) Improving the safety of embryo technologies: possible role of genomic imprinting Theriogenology 53 627-648

Young LE, Sinclair KD and Wilmut I (1998) Large offspring syndrome in cattle and sheep Reviews of Reproduction 3 155-163

Young LE, Fernandes K, McEvoy TG, Butterwith SC, Gutierrez CG, Carolan C, Broadbent PJ, Robinson J, Wilmut I and Sinclair KD (2001) Epigenetic change in IGF2R is associated with fetal overgrowth after sheep embryo culture Nature Genetics 27 153-154 